\title{
Bioavailability and potential carcinogenicity of polycyclic aromatic hydrocarbons from wood combustion particulate matter in vitro
}

\author{
Susanne Gauggel-Lewandowski ${ }^{\mathrm{a}, *}$, Alexandra H. Heussner ${ }^{\mathrm{a}}$, Pablo Steinberg ${ }^{\mathrm{b}}$, Bart Pieterse ${ }^{\mathrm{c}}$, \\ Bart van der Burg ${ }^{c}$, Daniel R. Dietrich ${ }^{\mathrm{a}}$ \\ ${ }^{a}$ Human and Environmental Toxicology, University of Konstanz, D-78457 Konstanz, Germany \\ b Institute for Food Toxicology and Analytical Chemistry, University of Veterinary Medicine Hannover, 30173 Hannover, Germany \\ ${ }^{\mathrm{c}}$ BioDetection Systems b.v., Science Park 406, 1098 XH Amsterdam, The Netherlands
}

Keywords:

Particulate matter

Polycyclic aromatic hydrocarbons

PAH CALUX ${ }^{\circledR}$

BALB/c 3 T3 cell transformation assay

Wood combustion

\begin{abstract}
A B S T R A C T
Due to increasing energy demand and limited fossil fuels, renewable energy sources have gained in importance. Particulate matter (PM) in general, but also PM from the combustion of wood is known to exert adverse health effects in human. These are often related to specific toxic compounds adsorbed to the PM surface, such as polycyclic aromatic hydrocarbons (PAH), of which some are known human car cinogens. This study focused on the bioavailability of PAHs and on the tumor initiation potential of wood combustion PM, using the PAH CALUX ${ }^{\circledR}$ reporter gene assay and the BALB/c 3T3 cell transformation assay, respectively. For this, both cell assays were exposed to PM and their respective organic extracts from varying degrees of combustion. The PAH CALUX ${ }^{\circledR}$ experiments demonstrated a concentration response relationship matching the PAHs detected in the samples. Contrary to expectations, PM samples from complete (CC) and incomplete combustion (IC) provided for a stronger and weaker response, respectively, suggesting that PAH were more readily bioavailable in PM from CC. These findings were corroborated via PAH spiking experiments indicating that IC PM contains organic components that strongly adsorb PAH thereby reducing their bioavailability. The results obtained with organic extracts in the cell transforma tion assay presented the highest potential for carcinogenicity in samples with high PAH contents, albeit PM from CC also demonstrated a carcinogenic potential. In conclusion, the in vitro assays employed emphasize that CC produces PM with low PAH content however with a general higher bioavailability and thus with a nearly similar carcinogenic potential than IC PM.
\end{abstract}

\section{Introduction}

Due to concerns regarding climate change and finite fossil fuel resources, the demand for renewable, $\mathrm{CO}_{2}$ neutral energy sources, increased [1]. In order to achieve economic but carbon neutral en ergy use some countries, e.g. Germany, support the combustion of wood, even in small scale furnaces with the effect that in $201092 \%$ of renewable energy consumed consisted of wood [2]. Yet, increas ing domestic wood combustion also enhances particulate matter (PM) emissions. PM from various combustion processes, e.g. diesel

Abbreviations: PM, particulate matter; PAH, polycyclic aromatic hydrocarbon; ANF, alpha-naphthoflavone; IC, incomplete combustion; CC, complete combustion. * Corresponding author. Address: Human and Environmental Toxicology, Department of Biology, University of Konstanz, P.O. Box X-918, 78457 Konstanz, Germany. Tel.: +49 (0)7531/88 3518; fax: +49 (0)7531/88 3170 .

E-mail addresses: susanne.gauggel@uni-konstanz.de (S. Gauggel-Lewandowski), alexandra.heussner@uni-konstanz.de (A.H. Heussner), Pablo.Steinberg@tiho-hannover. de (P. Steinberg), Bart.Pieterse@bds.nl (B. Pieterse), Bart.van.der.Burg@bds.nl (B. van der Burg), Daniel.Dietrich@uni-konstanz.de (D.R. Dietrich). exhaust particles (DEP), biomass smoke particles (BSP) and gaso line exhaust emissions have gained importance regarding possible adverse health effects in humans [ 3 5]. DEP has been classified as a human carcinogen [6]. BSP emissions were associated with approximately 1.5 million premature deaths per year due to sec ondary acute lower respiratory tract and chronic obstructive pul monary disorders (COPD) [7]. Both evaluations heavily rely on epidemiologic data. Consequently, the IARC evaluation, differing in interpretation with another recent expert team evaluation [8], nearly entirely relies on epidemiology studies derived from popu lations exposed to DEP (i.e. DEP generated in 1950 1980s) and not from cohorts exposed to new technology diesel exhaust particles (NTDEP). However, NTDEP, due to novel combustion and filter technologies, differ dramatically from DEP. This demonstrates the discrepancy between ongoing technological development and epi demiological evaluation of latent long term effects.

The alternative to epidemiological studies, i.e. using animal experimentation, has historically proven to be difficult as e.g. lung tumors in rats resulting from exposure to DEP are a reflection of 
PM lung overload rather than the true carcinogenic potential of the DEP, which has not been observed in other rodent species (re viewed by [8]). Moreover, evaluating adverse health characteristics of PM following each step of a technical development using animal studies is ethically, economically, and technically impossible. Thus a general reduction strategy, as achieved with diesel exhaust $>99 \%$ removal efficiency for a number of carcinogenic polycyclic aro matic hydrocarbons (PAH) and nitro PAH in NTDEP compared to traditional DEP), could be envisioned for all combustion PM. How ever, biomass combustion technology is extremely variable, rang ing from small private furnaces to large industrial biomass burners. With the increasing trend to burn biomass, total PM will most likely increase. Indeed, residential wood combustion has been calculated to significantly contribute to the amount of total $\mathrm{PAH}$ in emissions in Sweden and the US [9], while source appoint ment studies in Denmark demonstrated that residential wood burning was responsible for $47 \%$ of national $\mathrm{PM}_{2.5}$ emissions in 2002 [4]. Consequently, technological development of biomass burners require fast, reliable and economically feasible testing of PM generated to allow prospective assessment of potential risks. In view of the fact that, at least for the moment, the carcinogenic potential of PM from combustion processes appears of primary importance [6], one emphasis can be laid on the assessment of PM contaminants e.g. carcinogenic PAHs $[10,11]$. The current working hypothesis for technological advancement of wood burn ers is that the more efficient and complete the combustion, the lower the hazard potential of PM and by products, e.g. PAHs. How ever, the prediction of PAH toxicity is difficult to assess on the basis of mere chemical analysis with a limited number of prioritized PAHs, because in most cases the effects observed result from expo sure to $\mathrm{PAH}$ mixtures, with different PAHs having different toxic potentials. As the actual risk to humans also depends on the bio availability of PAH in inhalable PM, test systems are required allowing to understand the bioavailability as well as a toxicological summary endpoints (e.g. receptor interaction, foci formation).

The PAH CALUX ${ }^{\circledR}$ enables the quantification of PAH induced, AhR mediated activity and is based on the CALUX ${ }^{\circledR}$ technology, which has been used for screening of AhR active compounds (e.g. dioxins) in food, feed, sediments, pore water, waste, consumer products as well as marine biological matrices [12 16]. The $\mathrm{BALB} / \mathrm{c}$ 3T3 is an established cell transformation assay, simulating a two stage animal carcinogenicity test, to identify potential tumor initiating or tumor promoting substances $[17,18]$.

Consequently, to test whether complete combustions provide for toxicologically less potent PM than PM generated from incom plete combustion processes, organic extracts of wood combustion PM samples as well as the original PM samples were tested in the PAH CALUX ${ }^{\circledR}$ and the BALB/c 3T3 cell transformation assay.

\section{Materials and methods}

\subsection{Materials}

Unless stated otherwise, materials were purchased as follows: Steady $\mathrm{Glo}^{\circledR}$ (Promega, \#E2520), AhR antagonist alpha naphthof lavone (ANF) (\#N5757 1G), benzo[a]anthracene (\#1600917825), chrysene (\#101128480), benzo[a]pyrene (B[a]P) (\#087K0733), benzo[k]fluoranthene (\#101077504) and benzo[b]fluoranthene (\#1001015267), Sigma Aldrich; Indeno[c,d]pyrene (\#LB82005V), dibenzo[a,h]anthracene (\#4 8574), Supelco. Carbon black (CB), (Printex ${ }^{\circledR} 90$ ) was obtained from Degussa (Evonik industries, Ger many), encompasses $0.4 \%$ ash content (following ASTM D 1506), a BET surface area of $350 \mathrm{~m}^{2} / \mathrm{g}$ (following ASTM D 6556) and an average primary particle size of $14 \mathrm{~nm}$ (following internal method TGZ3). Activated charcoal (AC) was purchased from Riedel de Haën
(\#18002). All other materials were of the highest grade commer cially available.

\subsection{PM sampling}

Sampling of PM\#01 PM\#10 and their respective combustion characteristics are detailed in Table 1. Further information on sam pling of PM\#01, PM\#02 and PM\#05 was recently described by Gauggel et al., 2012 [19]. Sampling of PM\#03 and PM\#04 was car ried out in a test station of the German Biomass Research Centre in Leipzig, over the duration of 23 days and represent samples from an incomplete combustion. Common wood stoves (PM\#03 PM\#04: nominal output $10 \mathrm{~kW}$ ), were fired with commercially available non pretreated standard beech split logs $(1.3 \mathrm{~kg}$, specific humidity: $8.9 \%$ ) via hand loading every $1 / 2 \mathrm{~h}$. PM was collected in the ash pan of a standard electrostatic precipitator, $34 \mathrm{~m}$ away from the furnace, connected to the smoke tube. PM\#06 and PM\#07, representing samples from incomplete combustions, were collected after 270 and 245 min duration of combustion, respec tively. High quality wood stoves $(9.0 \mathrm{~kW}$ nominal output) in a test station of the German Biomass Research Centre were fired with commercially available non pretreated standard beech split logs $(1.3 \mathrm{~kg}$, specific humidity: $8.9 \%$ ) via hand loading every $1 / 2 \mathrm{~h}$. PM collection was carried out as described for PM\#01, PM\#03 and PM\#04. PM\#08 PM\#10 were obtained from separate combustions in an automatic pellet boiler at the German Biomass Research Cen tre, using "DIN plus" wood pellets. Whereas PM\#08 and PM\#10 represent complete combustion samples, PM\#09 resulted from the combustion under suboptimal conditions ( $15 \mathrm{~kW}$ nominal out put). All samples were obtained via an electrostatic precipitator.

\subsection{Particle characterization}

PM samples were characterized using several different meth ods, as previously described [19]. Scanning electron microscopy (SEM) for PM\#03, PM\#04 and PM\#06 PM\#10 was performed with a LEO 1530 at a voltage of $5 \mathrm{kV}$.

\subsection{Elementary (EC), organic carbon (OC), salt (Ion) and metal analysis}

EC was analyzed on the basis of the German VDI 24651 proto col [20]. EC/OC and ion analysis were carried out as previously de scribed [19]. Because of limited sample amount, determination of OC and EC could not be performed for PM\#03 and PM\#04. For me tal analysis the material was digested with conc. $\mathrm{HNO}_{3}$ supra pure in a microwave oven and analyzed for a series of metals with a ContrAA 700 atomic absorption spectrophotometer.

\subsection{PAH analysis}

PM\#01 PM\#10 were extracted according to DIN EN 15549 [21] and resulted in Extract\#01 Extract\#10, respectively (Table 2). Ex tracts were generated as previously described [19]. A subset (LPM\#06 LPM\#10) of the extracted (leached) PM, now described as leached particulate matter (LPM) were employed for direct experimentation in the PAH CALUX ${ }^{\circledast}$ system as well as for PAH spiking experiments (see below). The PAH content was also deter mined in activated charcoal and carbon black. While the PAH con tent of carbon black could not be measured with the available chromatograph, activated charcoal had a very low degree of PAH contamination (Table 2). The limit of detection (LOD) using GC MS was $40 \mathrm{ng}$ of each PAH ml ${ }^{-1}$. 
Table 1

Overview of PM samples and their combustion characteristics. All PM samples were obtained via an electrostatic precipitator. The results for PM\#01, PM\#02 and PM\#05 were previously published, but are presented here for ease of comparison of all PM samples [19]. Incomplete combustion (IC); complete combustion (CC).

\begin{tabular}{llll}
\hline Sample & Furnace & Fuel & Principle of combustion/remarks \\
\hline PM\#01 & Hand loaded single fire place (furnace) & Beech & Batch burning/incomplete combustion (IC) \\
PM\#02 & $\begin{array}{l}\text { Hand loaded single fire place } \\
\text { (tiled stove with ancillary heating unit) }\end{array}$ & $\begin{array}{l}\text { Wood briquette, split logs } \\
\text { (mixture of hard and soft wood) }\end{array}$ & $1.3 \mathrm{~kg}$ Beech standard split logs \\
PM\#03 & Hand loaded single fire place (furnace) & $1.3 \mathrm{~kg}$ Beech standard split logs & Batch burning/incomplete combustion (IC) \\
PM\#04 & Hand loaded single fire place (furnace) & DIN plus wood pellets & Complete combustion (CC) \\
PM\#05 & Automatically loaded fire place (wood pellet boiler) & 1.3 kg Beech standard split logs & Batch burning/incomplete combustion (IC) \\
PM\#06 & High-quality furnace & 1.3 kg Beech standard split logs & Batch burning/incomplete combustion (IC) \\
PM\#07 & High-quality furnace & DIN plus wood pellets & Complete combustion (CC) \\
PM\#08 & Pellet boiler & DIN plus wood pellets & Incomplete combustion (IC) \\
PM\#09 & Pellet boiler & DIN plus wood pellets & Complete combustion (CC) \\
PM\#10 & Pellet boiler & &
\end{tabular}

Table 2

Overview of chemical PAH analysis for PM\#01-PM\#10, activated charcoal (AC) and carbon black (CB). n.d. = not detected, n.a. = not analyzed. The results for PM\#01, PM\#02 and PM\#05 were previously published, but are presented here for ease of comparison of all PM samples [19]. Incomplete combustion (IC); complete combustion (CC).

\begin{tabular}{|c|c|c|c|c|c|c|c|c|c|c|c|c|}
\hline PAH amount (mg/kg) & $\begin{array}{l}\text { PM\#01 } \\
\text { (IC) }\end{array}$ & $\begin{array}{l}\text { PM\#02 } \\
\text { (IC) }\end{array}$ & $\begin{array}{l}\text { PM\#03 } \\
\text { (IC) }\end{array}$ & $\begin{array}{l}\text { PM\#04 } \\
\text { (IC) }\end{array}$ & $\begin{array}{l}\text { PM\#05 } \\
(\mathrm{CC})\end{array}$ & $\begin{array}{l}\text { PM\#06 } \\
\text { (IC) }\end{array}$ & PM\#07 (IC) & $\begin{array}{l}\text { PM\#08 } \\
(\mathrm{CC})\end{array}$ & $\begin{array}{l}\text { PM\#09 } \\
\text { (IC) }\end{array}$ & $\begin{array}{l}\text { PM\#10 } \\
(\mathrm{CC})\end{array}$ & $\mathrm{AC}$ & $\mathrm{CB}$ \\
\hline Naphthalene & 0.7 & $<4$ & 27.9 & 4 & $<0.4$ & 12.4 & 3.7 & 0.3 & 0.6 & 1 & 3.8 & n.a. \\
\hline Acenaphthylene & $<0.7$ & 6 & $<0.8$ & $<2$ & $<0.4$ & $<7$ & 0.3 & 0.4 & 0.9 & 1 & 0.4 & n.a. \\
\hline Acenaphthene & $<0.7$ & $<4$ & 1.4 & $<2$ & $<0.4$ & $<7$ & 0.3 & 0.1 & 0.2 & 0.1 & 0.3 & n.a. \\
\hline Fluorene & $<0.7$ & $<4$ & 0.9 & $<2$ & $<0.4$ & $<7$ & 0.4 & 0.2 & 0.8 & 0.5 & 0.4 & n.a. \\
\hline Phenanthrene & 2.5 & 75 & 6.4 & 3 & 0.8 & 44.2 & 2.3 & 2.5 & 6 & 3 & 0.7 & n.a. \\
\hline Anthracene & $<0.7$ & 15 & $<0.8$ & $<2$ & $<0.4$ & $<7$ & 0.5 & 1.1 & 2.1 & 1.2 & 0.8 & n.a. \\
\hline Fluoranthene & 2.9 & 142 & 3 & $<2$ & 1.3 & 11.1 & 1.6 & 3 & 5.4 & 3.3 & n.d. & n.a. \\
\hline Pyrene & 2.8 & 137 & 2.6 & $<2$ & 1.2 & 10.5 & 1.7 & 3.1 & 4.9 & 3.3 & n.d. & n.a. \\
\hline Benzo[a]anthracene & 2 & 42 & 1.3 & $<2$ & 0.7 & $<7$ & 1.5 & 3 & 1.4 & 3.3 & n.d. & n.a. \\
\hline Chrysene & 2.2 & 55 & 2 & $<2$ & 1 & $<7$ & 1.1 & 2.1 & 1.2 & 2.5 & n.d. & n.a. \\
\hline Benzo[b]fluoranthene & 8.9 & 63 & 3.8 & 3 & 1.8 & $<7$ & 1.8 & 3.7 & 0.9 & 4 & 0.5 & n.a. \\
\hline Benzo[k]fluoranthene & 2.6 & 20 & 1 & $<2$ & 0.5 & $<7$ & 0.8 & 1.7 & 0.2 & 1.9 & 0.4 & n.a. \\
\hline Benzo[a]pyrene & 7.8 & 26 & 1.3 & $<2$ & 0.7 & $<7$ & 1.3 & 3.1 & 0.4 & 3.3 & n.d. & n.a. \\
\hline Indeno[1,2,3-c,d]pyrene & 25.4 & 35 & 2.3 & 5 & 1.4 & $<7$ & 2.8 & 3.5 & 0.2 & 3.5 & n.d. & n.a. \\
\hline Dibenzo[a,h]anthracene & 2.8 & 4 & $<0.8$ & $<2$ & $<0.4$ & $<7$ & 0.3 & 0.6 & 0.1 & 0.5 & n.d. & n.a. \\
\hline Benzo[g,h,i]perylene & 24.1 & 28 & 2.2 & 4 & 1.2 & $<7$ & 2.6 & 3.1 & 0.2 & 3 & n.d. & n.a. \\
\hline Sum & 84.7 & 648 & 56.1 & 19 & 10.6 & 78.2 & 22.8 & 31.5 & 25.5 & 35.3 & 7.3 & n.a. \\
\hline
\end{tabular}

2.6. PAH spiking experiments with LPM, activated charcoal and carbon black

For spiking experiments leached particles (LPM\#06 LPM\#10), activated charcoal and carbon black particles were spiked with an artificial PAH mixture in DMSO mimicking the PAH profile of PM\#01 (PAH\#01) (Table 3). For this profile seven PAHs (out of the 16 US EPA PAHs) with the highest relative potencies in the PAH CALUX ${ }^{\circledR}$ assay were chosen, i.e. benzo[a]anthracene, chrysene, benzo[a]pyrene, benzo[k]fluoranthene, benzo[b]fluoranthene, in deno[c,d]pyrene and dibenzo[a,h]anthracene. These spiked particle suspensions were incubated for at least $16 \mathrm{~h}$ on a horizontal shaker at room temperature. Prior to exposure, all particle suspensions were mixed and ultrasonicated with an ultrasonic frequency of $35 \mathrm{kHz}$ (Elma T470/H, 50/60 Hz) for $10 \mathrm{~min}$.

\subsection{Cell culture of PAH CALUX ${ }^{\circledR}$ cells}

Cell culture of PAH CALUX ${ }^{\circledR}$ cells was performed as previously described [19].

\subsection{Sample preparation for PAH CALUX ${ }^{\circledR}$ cell testing}

Stock solutions $(10 \mathrm{mg} / \mathrm{ml}$ in $100 \%$ DMSO) of all samples (PM\#01 PM\#10, activated carbon or carbon black, LPM\#06 LPM\#10, PAH spiked samples) were prepared. Suspensions were mixed for $1 \mathrm{~min}$ and incubated in an ultrasound bath (Elma $\mathrm{T} 470 / \mathrm{H}, 50 / 60 \mathrm{~Hz}$ ) at $35 \mathrm{kHz}$ for $15 \mathrm{~min}$. Subsequently serial dilutions were prepared from the stock solutions resulting in treat ment concentrations of $45,14.4,4.6,1.4,0.46,0.21,0.1$ and $0.046 \mu \mathrm{g} / \mathrm{cm}^{2}$ in the wells. PM extracts, dissolved in dichlorometh ane, were evaporated under nitrogen flow to dryness and re dis solved in DMSO to a concentration of $50 \mathrm{mg} / \mathrm{ml}$, relative to the amount of PM sample that was used for extraction initially, thus representing the PM extract stock solution. Subsequently, serial dilutions were prepared from this stock solution with a dilution factor of 3.16 (10 concentrations).

\subsection{Bench top small scale combustion experiments with specific particulate matter (activated charcoal, PM\#02 and PM\#10)}

In order to investigate the PAH bioavailability in a specific par ticulate matter (activated charcoal, PM\#02 and PM\#10), additional small scale combustion experiments were performed (Table 3 ). Approximately $50100 \mathrm{mg}$ of sample was weighed into porcelain crucibles. After preliminary test combustions, a bench top muffle furnace (Heraeus Instruments Type M100, nominal temperature $1000{ }^{\circ} \mathrm{C}, 230 \mathrm{~V}, 50 / 60 \mathrm{~Hz}, 2.6 \mathrm{~A}, 0.6 \mathrm{~kW}$ ) was fired for $20 \mathrm{~min}$ at 400,600 and $800^{\circ} \mathrm{C}$. From the resulting samples stock solutions of $10 \mathrm{mg} / \mathrm{ml}$ in DMSO or spiking samples with PAH\#01 profile were prepared as well as serial dilutions as described above. These samples were tested in the PAH CALUX ${ }^{\circledR}$ assay. In a further exper iment activated charcoal samples at $10 \mathrm{mg} / \mathrm{ml}$ were spiked with PAH profile of PM\#01. After spiking, the DMSO was evaporated with nitrogen and the samples were also incinerated in the muffle furnace as described above. The same was experiment was 
Table 3

Overview of all samples tested in the PAH CALUX ${ }^{\circledR}$ and/or the BALB/c 3T3 assay. AC: activated charcoal; PM: particulate matter; ANF: alpha-naphthoflavone; PAH: polycyclic aromatic hydrocarbons; LPM: leached particulate matter; $\mathrm{CB}$ : carbon black; X: tested; n.t.: not tested.

\begin{tabular}{|c|c|c|}
\hline Sample & PAH CALUX ${ }^{\circledR}$ assay & $\mathrm{BALB} / \mathrm{c} 3 \mathrm{~T} 3$ assay \\
\hline PM\#01-PM\#05 & $\mathrm{X}$ & $\mathrm{X}$ \\
\hline PM\#06-PM\#10 & $\mathrm{X}$ & n.t. \\
\hline Extract\#01-Extract\#05 & $\mathrm{X}$ & $\mathrm{X}$ \\
\hline Extract\#06-Extract\#10 & $\mathrm{X}$ & n.t. \\
\hline ANF & $\mathrm{X}$ & n.t. \\
\hline PAH\#01 (PAH profile of PM\#01-artificial mixture of seven selected PAHs) & $\mathrm{X}$ & n.t. \\
\hline LPM\#06-LPM\#10 & $\mathrm{X}$ & Only LPM\#07 \& LPM\#10 \\
\hline LPM\#06-LPM\#10 + PAH\#01 & $\mathrm{X}$ & n.t. \\
\hline PM\#04 + diff. PAH\#02 & $\mathrm{X}$ & n.t. \\
\hline PM\#05 + diff. PAH\#02 & $\mathrm{X}$ & n.t. \\
\hline AC & $\mathrm{X}$ & $\mathrm{X}$ \\
\hline $\mathrm{CB}$ & $\mathrm{X}$ & $\mathrm{X}$ \\
\hline AC: $400,600,800^{\circ} \mathrm{C}$ & $\mathrm{X}$ & n.t. \\
\hline AC: $400,600,800^{\circ} \mathrm{C}+\mathrm{PAH \#} 01$ & $\mathrm{X}$ & n.t. \\
\hline $\mathrm{AC}+\mathrm{PAH} \# 01: 400,600,800^{\circ} \mathrm{C}$ & $\mathrm{X}$ & n.t. \\
\hline $\mathrm{AC}+\mathrm{PAH \# 01}+40 \% \mathrm{H}_{2} \mathrm{O}: 400,600,800^{\circ} \mathrm{C}$ & $\mathrm{X}$ & n.t. \\
\hline PM\#02: $400,600,800^{\circ} \mathrm{C}$ & $\mathrm{X}$ & n.t. \\
\hline PM\#10: $400,600,800^{\circ} \mathrm{C}$ & $\mathrm{X}$ & n.t. \\
\hline
\end{tabular}

repeated with the addition of $40 \%$ dest. $\mathrm{H}_{2} \mathrm{O}(\mathrm{v} / \mathrm{w})$, in order to test whether the water content has an impact on combustion quality.

\subsection{PAH CALUX ${ }^{\circledR}$ assay}

The assay was performed according to manufacturer's instruc tions and as previously described [19]. For data analysis the value for the vehicle control (0.8\% DMSO) was subtracted from all other values. A B $[\mathrm{a}] \mathrm{P}$ standard concentration response curve (asymmetric five parameter logistic equation) was calculated. The obtained lumi nescence values of the sample treated cells, were normalized by dividing the luminescence values by the maximum value obtained from the $\mathrm{B}[\mathrm{a}] \mathrm{P}$ standard curve on the same plate and given as percentage of this maximum value. In order to allow for a five parameter analysis of the B[a]P standard curve, individual outliers identified by a Grubb's test were omitted and anchorage points were set. The PAH CALUX ${ }^{\circledR}$ bioassay is capable of detecting pico grams (10 $12 \mathrm{~g}$ ) of benzo[a]pyrene equivalents (EQs) depending on the sample matrix. The limit of quantification (LOQ) of the PAH CALUX $^{\circledR}$ is approx. $6.2 \mathrm{pg} \mathrm{BaP} \mathrm{EQ/well.} \mathrm{In} \mathrm{order} \mathrm{to} \mathrm{verify} \mathrm{Ah} \mathrm{receptor}$ activation due to PAH binding, exposure experiments with alpha naphthoflavone (ANF), an inhibitor of the Ah receptor, were performed. This demanded cell pretreatment with ANF via medium containing $0,1,10$ or $40 \mu \mathrm{M}$ ANF (final DMSO concentration of $0.8 \%$ $(\mathrm{v} / \mathrm{v}))$. After $1 \mathrm{~h}$ exposure the medium was discarded and cells were exposed to selected $\mathrm{B}[\mathrm{a}] \mathrm{P}$ standards as described above.

\subsection{BALB/c $3 T 3$ cell transformation assay}

The BALB/c 3T3 clone A31 11 , initially from the laboratory of Makoto Umeda (Hatano Research Institute) was kindly provided by Dr. A. Poth (Harlan Cytotest Cell Research, Roßdorf, Germany). Cells were grown in minimum essential medium from Invitrogen (Karlsruhe) supplemented with 10\% fetal bovine serum (Moregate, Bulimba, Australia), $100 \mathrm{mg} / \mathrm{ml}$ streptomycin, and $100 \mathrm{U} / \mathrm{ml}$ peni cillin (Biochrom, Berlin, Germany) under standard humidified con ditions $\left(37^{\circ} \mathrm{C}, 5 \% \mathrm{CO}_{2}\right)$. Cells were passaged after reaching $80 \%$ confluence, and a working stock of this passage 1 cells was frozen in liquid nitrogen in a medium consisting of $80 \%$ minimum essen tial medium, 10\% fetal bovine serum, and 10\% DMSO until further experimentation. The ability of the PAH extracts and particles to malignantly transform BALB/c 3T3 cells was tested by performing the two stage cell transformation assay according to [22] with slight modifications. Briefly, exponentially growing BALB/c 3T3 cells were plated at a density of 2000 cells/well of a 6 well plate in $2 \mathrm{ml}$ of DMEM/F12 medium (Biochrom, \#F0815) supplemented with 10\% FBS (Biochrom, \#S0115), 10,000 units/ml penicillin, $10,000 \mu \mathrm{g} / \mathrm{ml}$ streptomycin (Biochrom, \#A2213) and $200 \mathrm{mM} \mathrm{L}$ glutamine (Biochrom, \#K0283). Following $24 \mathrm{~h}$ maintenance in cell culture medium, BALB/c 3T3 cells were exposed to treatment cul ture medium, i.e. cell culture medium containing extracts diluted in DMSO or particles, for 7 days. Subsequently (i.e. on day eight of the assay) exposure medium was replaced by medium contain ing $0.3 \mathrm{mg} 12 \mathrm{O}$ tetradecanoylphorbol 13 acetate (TPA)/ml and the culture maintained up to day 22 in TPA containing medium. Thereafter TPA containing cell culture medium was replaced and the BALB/c 3T3 cells cultured for another 3 weeks in normal cell culture medium. At the end of week 6 BALB/c 3T3 cells were fixed in methanol and stained with Giemsa solution. The cell culture media (normal, treatment or TPA) were renewed every 34 days.

$\mathrm{BALB} / \mathrm{c}$ 3T3 cells treated with 3 methylcholanthrene $(0.1 \%$ DMSO (v/v)) for 7 days [23] served as positive control. Type III foci comprised of strongly basophilic cells, show massive piling up, invading the surrounding cell monolayer. Such foci have also been reported to form sarcomas upon subcutaneous injection in irradi ated $\mathrm{C} 3 \mathrm{H}$ mice. These type III foci were identified and scored in the current study according to [24]. Type III foci of less than $3 \mathrm{~mm}$ in diameter were not scored.

Extract samples were tested in three independent replicates $(n=3)$. However, due to sample limitations only two independent replicates for each PM sample could be analyzed $(n=2)$. For the di rect comparison of the extracts, Type III foci numbers were normal ized based on the different $\mathrm{B}[\mathrm{a}] \mathrm{P}$ contents of the PM extracts. Subsequently, samples were normalized by setting Extract\#01 $=1$.

\subsection{Statistical analysis}

PAH CALUX ${ }^{\circledR}$ assay results are expressed as the mean with stan dard error of means for at least three replicates unless otherwise stated. Data were analyzed using one way ANOVA followed by Bonferroni or Dunnett́s post test as indicated (GraphPad Prism ${ }^{\circledR}$ version 5.04.). In the BALB/c 3T3 cell transformation assay results are given as mean with standard deviations and a one way ANOVA with Dunnett's Multiple Comparison Test was used for statistical testing of extract results.

\section{Results}

To better distinguish and classify the different samples and the degree of combustion quality, in this manuscript, the PM stemming 
from a more efficient and optimized combustion (pellet boiler) are termed as samples from complete combustion (CC), although from a very strict point of view, these samples were not completely oxi dized to $\mathrm{CO}_{2}$ and $\mathrm{H}_{2} \mathrm{O}$ as there are still some carbon compounds remaining, as also demonstrated by the light grey color of the PM. In contrast, PM stemming from hand loaded furnaces (batch burning) or a pellet boiler operated under suboptimal conditions are referred to as PM from incomplete combustion (IC), as also demonstrated by the dark black color of the PM.

\subsection{Particle characterization}

All PM samples, of which PM\#01, PM\#02 and PM\#05 were al ready described by this laboratory [19], were characterized for their zeta potential (data not shown), particle size (Zetasizer and Mastersizer; Table S4, Supplementary data), particle morphology and homogeneity (Fig. S2, Supplementary data) and size distribu tion (Figs. S3 and S4, Supplementary data). Complete combustion appeared to produce slightly larger and more homogeneous parti cles than in incomplete combustion as judged by SEM (Fig. S2) and Mastersizer determinations (Fig. S4). The SEM images revealed a very inhomogeneous particle morphology and size distribution (Fig. S2). The suspensions $(0.1$ or $1 \mathrm{mg} / \mathrm{ml}$ ) in standard cell culture medium were tested for aggregation via the zeta potential (a sus pension with a zeta potential between -30 and $+30 \mathrm{mV}$ is regarded as instable suspension ${ }^{1}$. The values for PM\#01 PM\#10 (data not shown) as well as the test particles laid between -7 and $-13 \mathrm{mV}$, thus suggesting an instable suspension, favoring aggregation. How ever, the zeta potential is strongly influenced by the $\mathrm{pH}$ of the med ium employed for generating the suspensions [25], thus possibly explaining the similar zeta potential for all PM suspensions, irrespec tive of the PM types. Table S4 and Fig. S3 show the number weighted mean particle size as well as the particle size distribution measured in the Zetasizer. All particles were in a similar size range with mean particle sizes between 100 and $200 \mathrm{~nm}$, whereas PM\#10 had the smallest mean particle size with $57 \mathrm{~nm}$ and activated charcoal the biggest with $479 \mathrm{~nm}$. Similar to these trends were the findings in the Mastersizer (Fig. S4). The median diameters $(d(0.5))$ in Table S4 corresponded approximately to the peaks of the samples shown Fig. S4. It is noticeable, that the measurements of all samples from complete combustion (PM\#05, PM\#08, PM\#10) revealed med ian diameters $(d(0.5))$ that were higher than the mean values from the Zetasizer. As the Mastersizer is more suitable for detecting coar ser particles with mean diameters up to $2000 \mu \mathrm{m}$, it appears that the complete combustion samples consist of very fine, but also of a coar ser fraction compared to most of the samples from incomplete com bustion. Activated charcoal also contained coarser particles with $d(0.5)$ of $1307 \mathrm{~nm}$.

\subsection{Elementary (EC), organic carbon (OC), salt (Ion) and metal analysis in PM samples}

As presumed, samples from complete combustion (PM\#05, PM\#08 and PM\#10) had the lowest total carbon (TC) values of all samples measured, whereas samples from incomplete combus tion all had higher TC values (Fig. 1). All samples, with the excep tion of PM\#03 and PM\#04, had moderate to high total salt contents ( $\geqslant 300 \mathrm{mg} / \mathrm{kg}$, Table $2 \mathrm{~S}$ ). An extremely high salt content was observed for PM\#01, suggesting that these highly variable salt contents may depend on wood type or handling conditions (con tamination) during wood harvesting [26]. The metals analyzed showed some variation amongst PM samples (Table S3). Potassium

\footnotetext{
1 Zetasizer Nano User Manual, MAN0317 Issue 5.0 August 2009, () Malvern Instruments Ltd. 2003-2008, 2009.
}

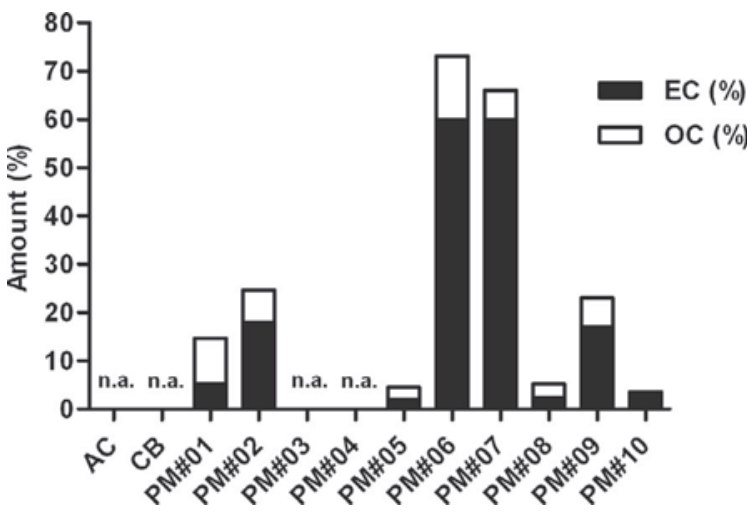

Fig. 1. Amount (\% of dw) of elementary (EC) and organic (OC) of PM samples. n.a., not analyzed due to limited sample amount. The results for PM\#01, PM\#02 and PM\#05 were previously published, but are presented here for ease of comparison of all PM samples [19]. AC: activated charcoal, CB: carbon black.

(K) was found in relatively high and highly variable concentrations in all PM. A remarkably high amount of iron ( $\mathrm{Fe})$ was found in PM\#02.

\subsection{PAH analysis}

Contrary to expectations, complete combustion did not gener ally lead to lower PAH values (see PM\#08 and PM\#10, Table 2) de spite that the same energy source (wood pellets) and furnace (pellet boiler) was used (Table 1). In general, the differences in PAH amount between the samples obtained in a pellet boiler (PM\#05, PM\#08 PM\#10) were negligible. Of all samples PM\#02 had the highest PAH amount.

\subsection{B[a]P concentration response in PAH CALUX ${ }^{\circledR}$ with/without the AhR antagonist (alpha naphthoflavone, ANF)}

To characterize the AhR response in the PAH CALUX ${ }^{\circledR}$ cells em ployed with regard to $\mathrm{B}[\mathrm{a}] \mathrm{P}$ responsiveness, concentration re sponse curves were established with B[a]P (Fig. S1A, Supplementary data). In addition, a concentration response curve was established for selected $\mathrm{B}[\mathrm{a}] \mathrm{P}$ with and without ANF pretreat ment using DMSO and three different concentrations of the AhR antagonist ANF (Fig. 2). Addition of DMSO had no effect at the three lowest $\mathrm{B}[\mathrm{a}] \mathrm{P}$ concentrations, whereas a significant effect was ob served at the two highest concentrations, when compared to sam ples without ANF pretreatment. Competition with ANF demonstrated that high ANF concentrations $(40 \mu \mathrm{M})$ induced a low luciferase response even at $\mathrm{B}[\mathrm{a}] \mathrm{P}$ concentrations where no re sponse was observed for the corresponding treatment controls. These data corroborated earlier findings that ANF can induce low signal transduction response despite its antagonistic characteristic $[27,28]$. B[a]P antagonism by ANF was observed only at the two highest ANF concentrations (10 and $40 \mu \mathrm{M}$ ) employed. This ANF mediated AhR antagonism was detectable only at $\mathrm{B}[\mathrm{a}] \mathrm{P}$ concentra tions $\geqslant 10^{-7} \mathrm{M}$. These data demonstrate that $\mathrm{B}[\mathrm{a}] \mathrm{P}$ concentrations $\geqslant 10^{-7} \mathrm{M}$ can be reliably detected with the PAH CALUX ${ }^{\circledR}$ system and that antagonistic molecules would have to be present at very high concentrations to quench the $\mathrm{B}[\mathrm{a}] \mathrm{P}$ mediated signal transduc tion response.

\subsection{Concentration response of PM and PM organic extracts in the PAH CALUX ${ }^{\circledR}$}

The PAH CALUX ${ }^{\circledR}$ luciferase concentration response curves generated with PM samples \#01 \#10 and the organic extracts 


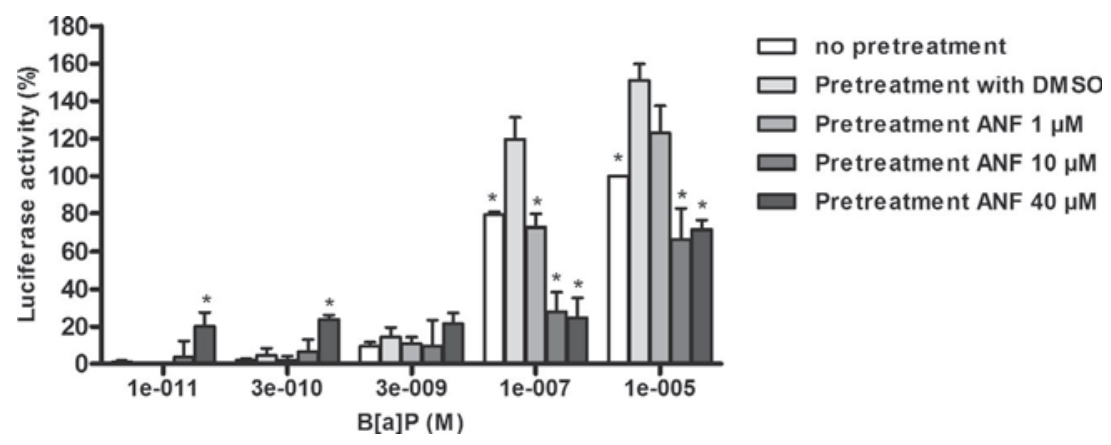

Fig. 2. Luciferase activity of PAH CALUX ${ }^{\circledR}$ cells with ANF pretreatment $(1 \mathrm{~h})$ prior to exposure to different benzo[a]pyrene standards. Luciferase activity is expressed in \% of the maximum value of a B[a]P standard. Mean \pm SEM $(n=3)$. One-way ANOVA with Dunnett's Multiple Comparison Test, ${ }^{*} p<0.1$ (control: pretreatment with $0.8 \%$ DMSO).

thereof were comparable to the response curve generated with pure B[a]P, i.e. having a full or partially sigmoid shape (Fig. 3). Con trary to initial expectations, PM samples from CC (PM \#05, \#08 and \#10) generally provided for a stronger concentration response than PM samples from IC. Only PM\#01 and \#02, from IC, contain ing the highest PAH concentrations (Table 2), induced a stronger luciferase response (left parallel shift of the concentration re sponse curve) than PM\#05 (Fig. 3A and B). However, it must be noted that the $>18$ fold concentration of PAH in PM\#02 than pres ent in PM\#05 (Table 2) is not reflected accordingly in the luciferase response, thus suggesting varying bioavailability of the PAHs pres ent in the PM samples. This interpretation is corroborated by the fact that the organic extracts of the PM samples demonstrate a completely different luciferase response than the original PM sam ples (Fig. 3 C and D). Indeed, while extracts of PM\#01 and PM\#02 still provide for the strongest luciferase response, the differences as observed in the original PM samples is no longer apparent, i.e. the extract of PM\#01 providing for a stronger response than PM\#02. Generally all PM organic extracts provided for a left shift of the concentration response curve observed in the original samples (Fig. 3), however as indicated earlier in some cases, e.g. PM\#03 and PM\#04 the left shift response of the organic extract appeared to be much greater than for other PM samples thereby supporting the hypothesis that the organic extraction made PAH biologically available that could have been more strongly adherent in the origi nal PM samples. The data however do indicate that PAH from com plete combustions could be more readily biologically available and that organic extracts of PM samples could provide for a false inter pretation of bioavailability in in vitro systems.

\subsection{Differential bioavailability of PAHs in spiked samples}

To further elucidate the differential bioavailability of the PAHs in the PM samples in contrast to organic extract samples, spiking experiments were performed. Seven PAHs (chrysene, benzo[a]anthracene, benzo[b]fluoranthene, benzo[k]fluoranthene, benzo[a]pyrene, dibenzo[a,h]anthracene and indeno[c,d]pyrene) were mixed (PAH\#01) to mimic the composition of the PAH profile of PM\#01 and tested in the PAH CALUX ${ }^{\circledR}$ (Fig. S1B). In addition, PM particle samples \#06 \#10 were extracted with organic solvent to obtain PAH free particles, so called leached particles (LPM\#06 LPM\#10) with similar particle characteristics as those of the origi nal untreated PM particle samples. When tested in PAH CALUX ${ }^{\circledR}$, no significant increase in luciferase activity was detected for LPM\#06 LPM\#10 (data not shown). However, when spiked with PAH\#01, the response in the PAH CALUX ${ }^{\circledR}$ revealed a concentra tion dependent increase in luciferase activity (Fig. 4A), which was significantly higher (as confirmed by one way ANOVA with Bonferroni post test) for LPM\#08 (CC) and LPM\#10 (CC) than for PM from IC (LPM\#06, LPM\#07, and LPM\#09). This thus confirmed that differences in the particle characteristics were solely responsi ble for the availability of an identical amount and mix of PAH and that CC provides for a greater bioavailability of PAH than IC. To fur ther confirm these findings two PM samples with comparable total $\mathrm{PAH}$ contamination (Table 2) were selected, one from an IC (PM\#04) and another from a CC (PM\#05). Both original PM sam ples \#04 and \#05 were spiked with PAH, thus adding addtl. PAH congeners (chrysene, benzo[a]anthracene, benzo[b]fluoranthene, benzo[k]fluoranthene, benzo[a]pyrene, dibenzo[a,h]anthracene and indeno[c,d]pyrene) to the already present PAH profile of $\mathrm{PM \# 04}$ and PM\#05 to arrive at the PAH profile of PM\#02. The anal ysis of activity in the PAH CALUX ${ }^{\circledR}$ resulted in a higher response of PM\#05 despite a comparable PAH profile (Fig. 4B), thus corroborat ing further the finding that $\mathrm{PAH}$ might be more readily bioavailable from PM stemming from CC processes. Moreover, a similar spiking experiment carried out with PAH\#01 in activated charcoal and car bon black further supported this interpretation (data not shown).

\subsection{Bench top small scale combustion experiments with test particles (activated charcoal) and PM samples}

Bench top combustion experiments were performed in order to study whether temperature during combustion affects PAH bio availability. Activated charcoal (AC), PM\#02 (IC) and PM\#10 (CC) as well as three temperatures $\left(400,600\right.$ and $\left.800^{\circ} \mathrm{C}\right)$ and a combus tion time of 20 min were used for experimentation (Table 3). At $400{ }^{\circ} \mathrm{C}$ the AC sample did not show any significant morphological change, whereas at 600 and $800{ }^{\circ} \mathrm{C}$ the sample amount was clearly reduced and the remaining samples were of light grey color. The incinerated AC and AC samples spiked with PAH\#01 or PAH\#01 $+40 \% \mathrm{H}_{2} \mathrm{O}$ showed no increased luciferase activity in the PAH CALUX ${ }^{\circledast}$ Assay (data not shown), thus indicating that either the PAH were destroyed during combustion, or that the PAH are not biologically available due to particle adherence. However, incin erated AC spiked with PAH\#01 following incineration at 600 and $800^{\circ} \mathrm{C}$, demonstrated an increased luciferase response in the PAH CALUX $^{\circledR}$ (Fig. 4C). This thus suggests that combustion at $400^{\circ} \mathrm{C}$ re sulted in a minimal modification of the particle surface area and in strong PAH adherence, while the higher temperatures resulted in a combustion of AC to particles with less PAH adherence capabil ities. In order to understand whether additional combustion of PM\#02 and PM\#10 would change PAH bioavailability, these PM samples were incinerated at 400,600 and $800^{\circ} \mathrm{C}$ and subsequently tested in the CALUX ${ }^{\circledR}$ assay. Upon incineration PM\#02 changed slightly in color from black to brown. PM\#10 dramatically changed its color from light grey to black at 600 and $800{ }^{\circ} \mathrm{C}$.

\subsection{BALB/c $3 T 3$ cell transformation assay}

The BALB/c 3T3 cell transformation assay was employed to investigate the tumor initiating capacity of PM extracts and 

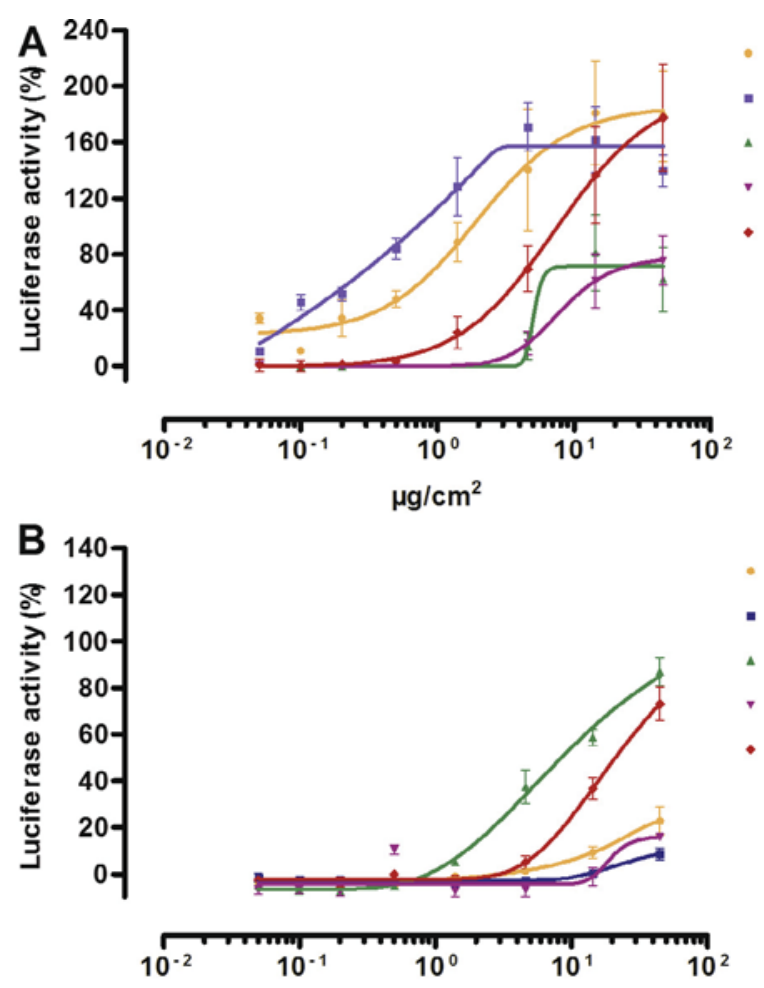

PM\#01 (IC)

- PM\#02 (IC)

4 PM\#03 (IC)

- PM\#04 (IC)

- PM\#05 (CC)

$\mu \mathrm{g} / \mathrm{cm}^{2}$

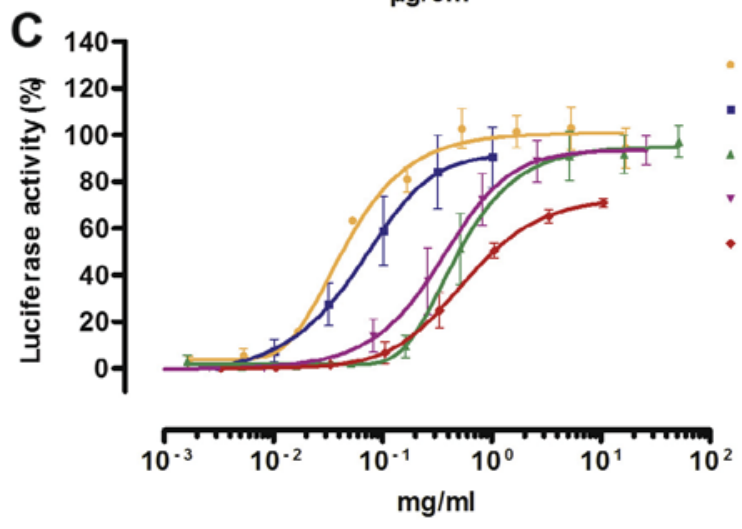

PM\#06 (IC)

- PM\#07 (IC)

4 PM\#08 (CC)

- PM\#09 (IC)

- $\mathrm{PM \# 10} \mathrm{(CC)}$

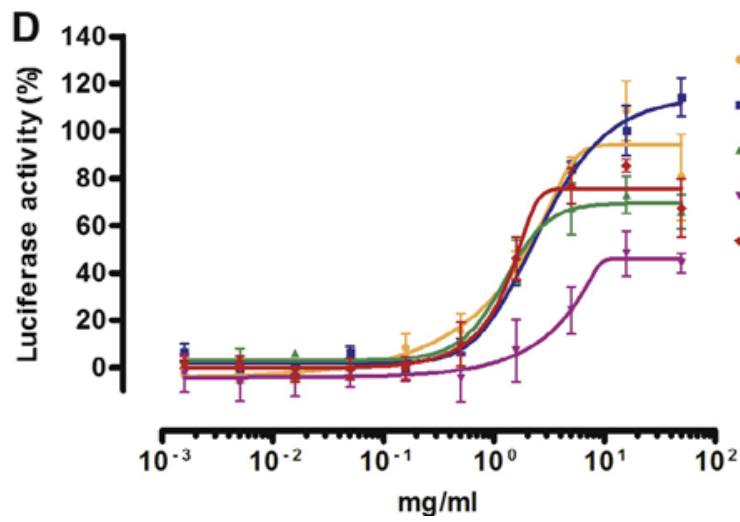

Extract\#01 (IC)

Extract\#02 (IC)

Extract\#03 (IC)

Extract\#04 (IC)

- Extract\#05 (CC)

Fig. 3. Luciferase activity in the PAH CALUX ${ }^{\circledR}$ assay of PM\#01-PM\#10 (A and B) and their respective Extracts\#01-Extracts\#10 (C and D). The results for PM\#01, PM\#02 and PM\#05 were previously published, but are presented here for ease of comparison of all PM samples [19]. Luciferase activity is expressed in\% of the maximum value of a B[a]P standard. Mean $\pm \operatorname{SEM}(n=3)$. Please note different $y$-axis scale in A.

original PM. For extract testing all samples were diluted on the ba sis of their $\mathrm{B}[\mathrm{a}] \mathrm{P}$ concentration and adjusted in a range between $1 \mathrm{E} 10$ and $1 \mathrm{E} 15 \mathrm{M}$. All extract samples showed a significant in crease in foci $(\geqslant 3 \mathrm{~mm})$ number per well compared to DMSO con trol, but not for all dilutions (Fig. 5A E). Some dilutions of the samples were in the same range or even higher (Extract\#02, Ex tract\#03) than the positive control (MCA/TPA). Of all samples tested, only Extract\#02 and Extract\#04 showed a concentration dependent decrease in foci number with lower concentrations. The controls (MCA/, /TPA, DMSO/TPA) were all in the same range. 

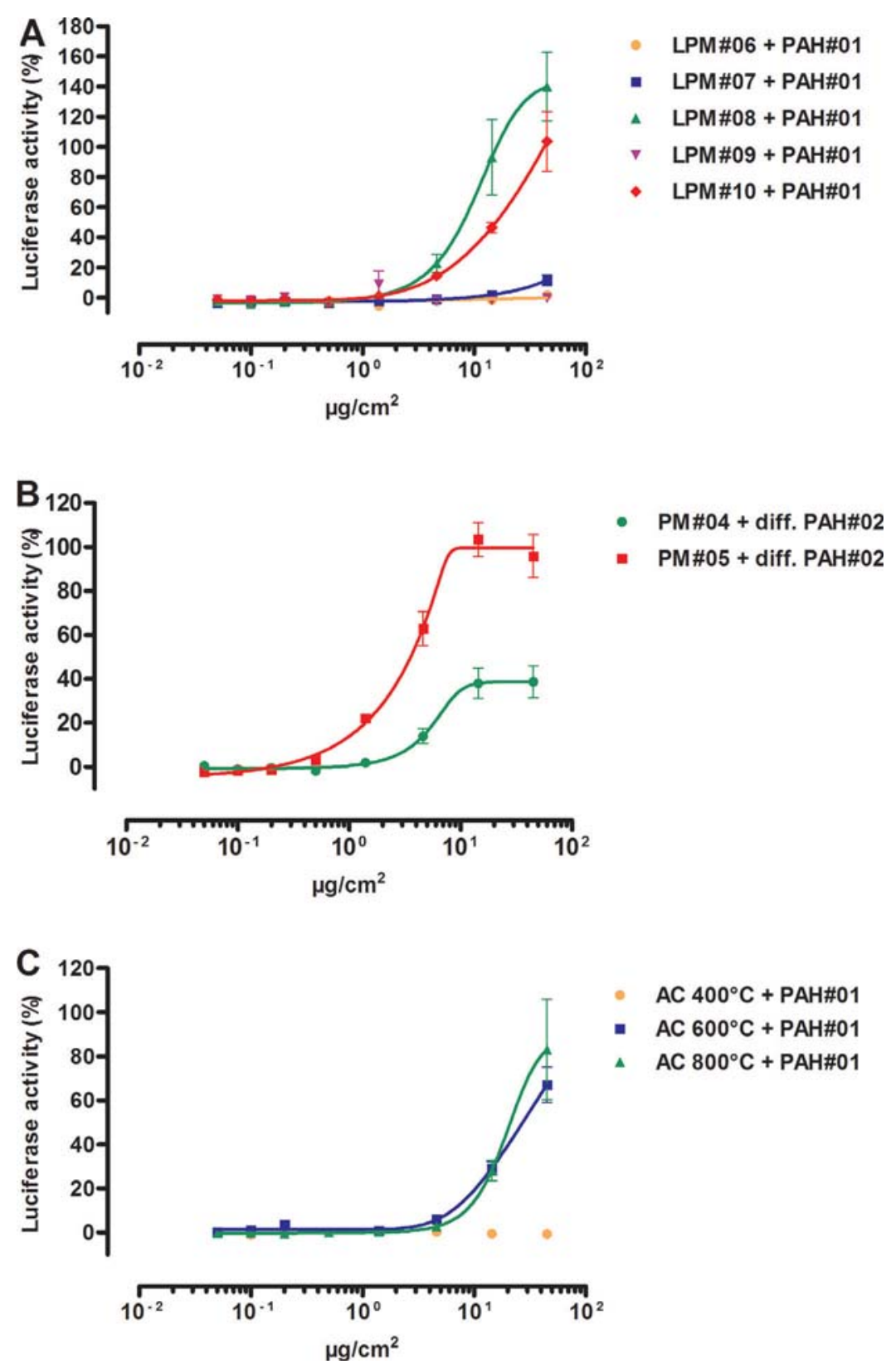

Fig. 4. Luciferase activity in the PAH CALUX ${ }^{\circledR}$ assay. (A) LPM\#06-LPM\#10 spiked with the PAH profile of PM\#01 (PAH\#01). Mean \pm SEM $(n=3$ ); (B) PM\#04 (incomplete combustion) and PM\#05 (complete combustion) spiked with the differential PAH profile of PM\#02. Mean \pm SEM $(n=4)$; (C) combusted activated charcoal spiked with $\mathrm{PAH} \# 01$. Mean \pm SEM $(n=3)$. Luciferase activity is expressed in $\%$ of the maximum value of a B[a]P standard.

Upon normalization of the extract results (Fig. 5F) on the basis of their original B[a]P amount, a similar picture as in the CALUX ${ }^{\circledR}$ as say was obtained, which also fitted well with the total PAH pattern of chemical PAH analysis. The results for the tested PM samples were not as clear as for the extracts (Fig. 6). There was a higher var iability between the samples as well as between the different con centrations applied. All samples, except PM\#05, showed foci formation above that of the DMSO control, but the most consider able foci formation was detected for PM\#02 where all concentra tions were on the same level as MCA, the positive control for initiation. Contrary to expectations, of all samples tested, PM\#04 induced the highest number of foci formation as PM as well as ex tract. This could suggest that the concentration and type of individ ual PAH present in the particle mixture as well as in the ensuing extract governs the strength of foci initiation.

\section{Discussion}

The main difficulty of assessing potential hazards and thus risk of PM in humans is the fact that PM is extremely heterogeneous. Consequently, a thorough physico chemical characterization of the PM studies is key to understanding the potential bioavailability of PM and its constituents in any biological testing system. PM from wood combustion may form larger aggregates, primarily depending on the type and quality of the biomass at the outset as well as on the conditions of the combustion process itself $[29,30]$. Aggregation studies in cell culture media appear a good descriptor of the likely behavior in the lungs, whereas similar stud ies in water as solution medium are not [19]. The corresponding physico chemical characterization of the wood combustion PM employed in this study, demonstrated no explicit differences 

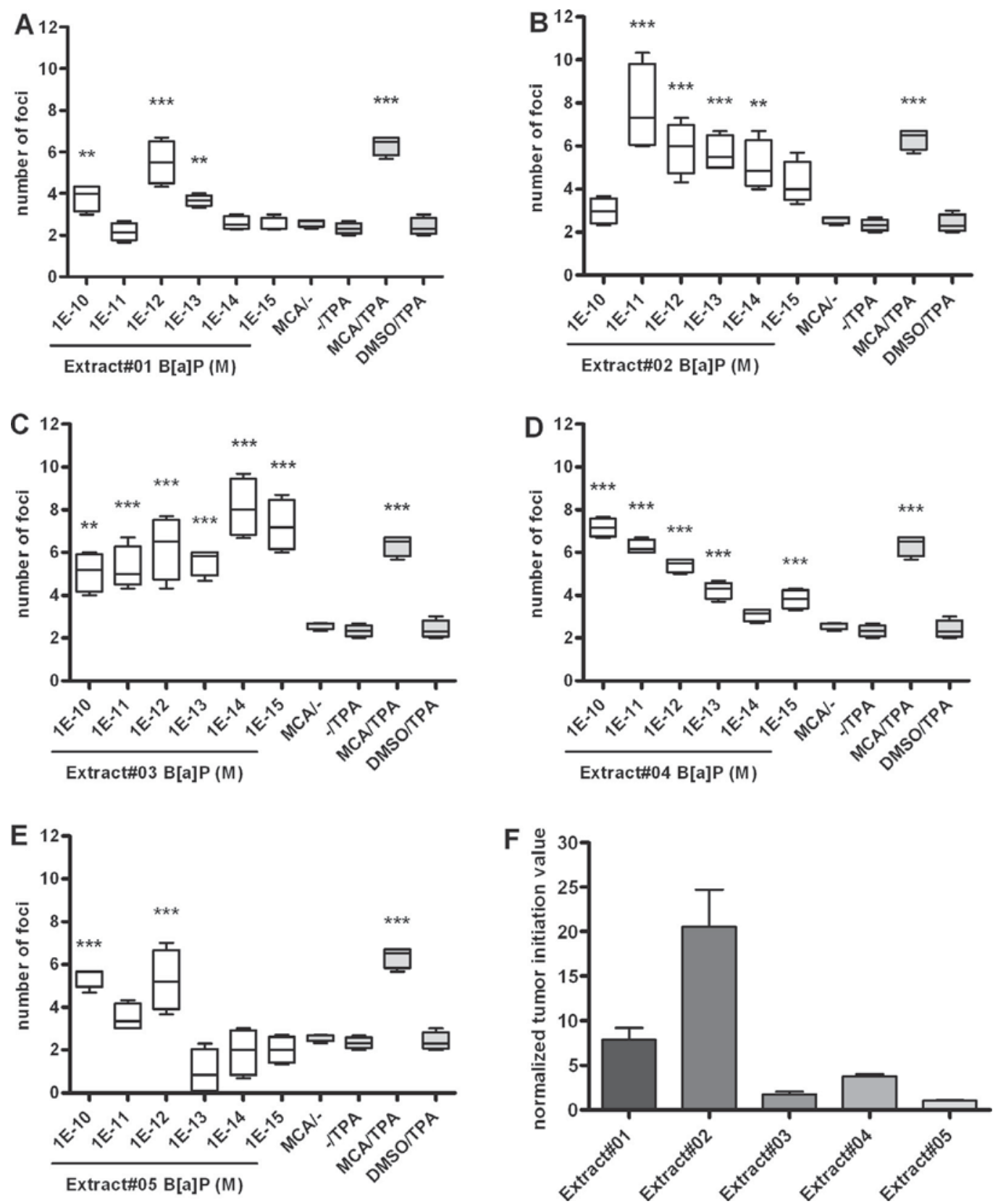

Fig. 5. Number of foci $(\geqslant 3 \mathrm{~mm})$ in BALB/c $3 \mathrm{~T} 3$ cell transformation assay upon exposure with PM extracts \#01-\#05 (A-E). Extract dilutions were adjusted to B[a]P amount. Shown are the median, box and whiskers: $\min$ to $\max (n=4)$. One-way ANOVA with Dunnett's Multiple Comparison Test (control: DMSO), ${ }^{* *} p<0.01$, ${ }^{* * *} p<0.001$. Direct comparison of normalized extracts for the highest concentrations, Mean \pm SD $(n=4)$ (F). MCA: methylcholanthrene, TPA: 12-O-tetradecanoylphorbol-13-acetate.

concerning particle size distribution and particle aggregation be tween CC and IC, whereas contrary to expectation, CC PM tended to provide for larger aggregates in the Mastersizer measurements (Table S4, Fig. S4). In general, an optimized combustion (CC) is known to produce less emissions and smaller particles than IC [31,32]. It is possible that the type of particle collection via an elec trostatic precipitator, as performed in this study, strongly influ enced the particle size as well as potential contaminations of the collected samples. For instance, smaller particles could influence larger particles, resulting in reduced precipitator efficiency for cer tain sizes [33]. The occurrence of metals is strongly dependent on the type of fuel used, as exemplified by PM\#02 containing a high amount of iron. This PM was the only sample obtained from private household. It is likely that this high Fe concentration resulted from the use of waste wood. Indeed, comparison of different fuels re vealed that waste wood is often contaminated with heavy metals [34]. PM\#02 also contained the highest amount of total PAH. As PAH analyses would suggest that PM from IC could have higher concentrations of PAH than the corresponding PM from CC, one would also assume that PM from IC provides for a greater health risk to humans [30]. Indeed, support for this interpretation is pro vided by a study that compared the adverse effects of smouldering combustion and normal combustion, demonstrating a higher inflammatory and cytotoxic potential for PM from smouldering combustion [35]. The study however also addresses a completely different exposure and health effects scenario. While smouldering combustion PM exposure primarily affects the persons located in close proximity to the combustion source and mostly in closed pre mises, PM from "normal" combustion sources, whether CC or IC, expose persons at a greater distance. Moreover, cytotoxicity and 

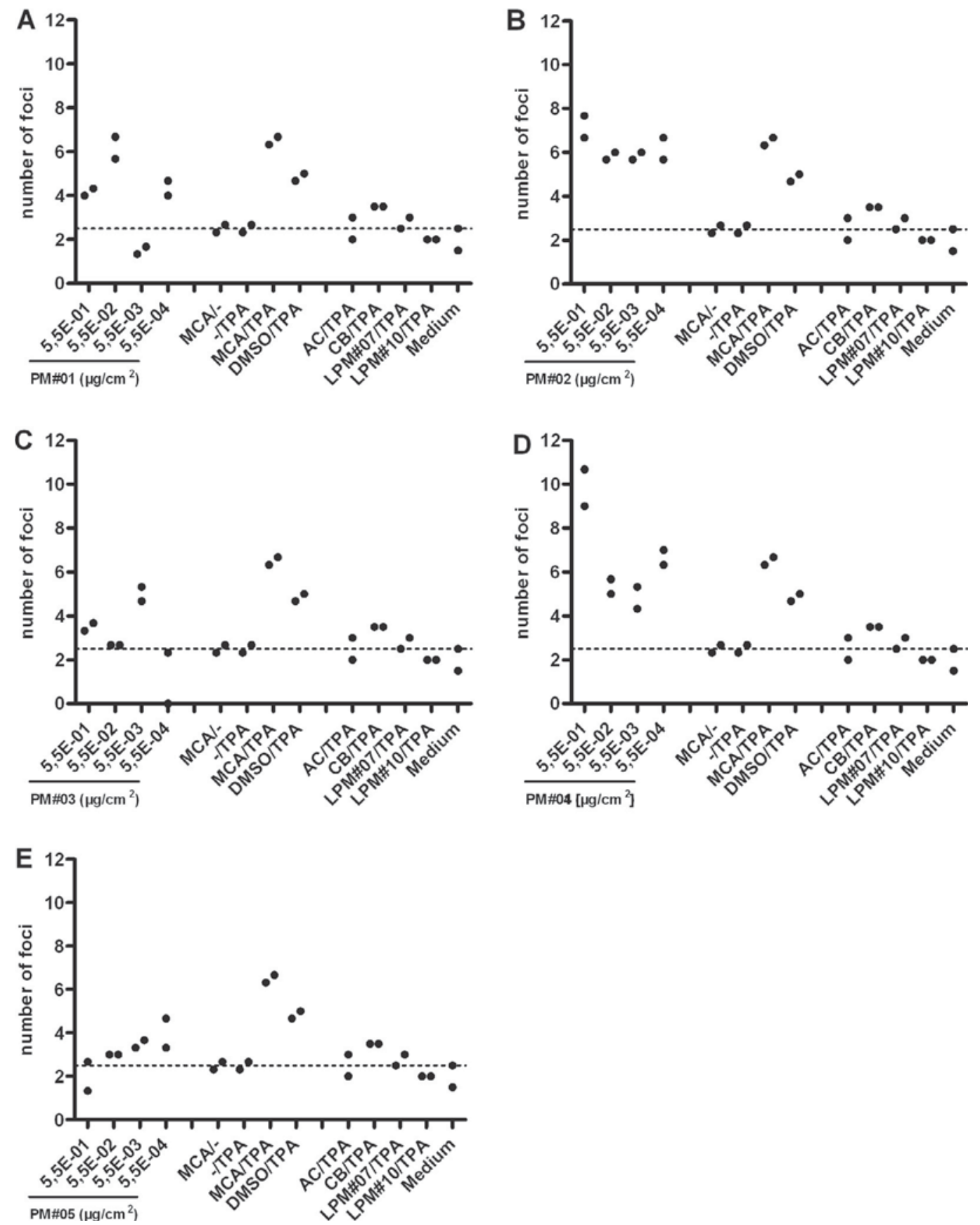

Fig. 6. Number of foci $(\geqslant 3 \mathrm{~mm}$ ) in BALB/c $3 \mathrm{~T} 3$ cell transformation assay upon exposure with PM \#01-\#05 (A-E). Scatter plot of two independent replicates. Due to limited sample amount only two independent replicates were measured. For better comparison with controls dotted line was set at 2.5 which refers to the mean of the MCA/- and TPA controls. MCA: methylcholanthrene, TPA: 12-O-tetradecanoylphorbol-13-acetate, AC: active charcoal, CB: carbon black, LPM\#07: leached PM\#07, LPM\#10: leached PM\#10.

acute inflammation would give rise to acute or subacute lung dam age not primarily resulting from exposure to high PAH concentra tions but rather from a macrophage and particle loading related generation of ROS. In contrast, the concern with PAH loading of PM from CC and IC primarily lies within the potential for chronic lung tissue damage and tumorigenicity.

As stated initially, it was expected that the samples from IC would induce higher responses in the PAH CALUX ${ }^{\circledR}$ assay. Indeed, testing of PM organic extracts resulted in a completely different reaction pattern than achieved with the original PM particles (Fig. 3), suggesting that organic extracts from PM had a greater receptor interaction activity in the PAH CALUX ${ }^{\circledR}$ and thus likely overestimated the potential toxicity. A similar observation was made in the BALB/c 3T3 cell transformation assay, where e.g. the extracts of $\mathrm{PM \# 02}$ provided for a greater number of foci than PM\#04 (Fig. 5), while the corresponding analysis with the original particles of PM\#02 and PM\#04 did not demonstrate any difference between these samples (Fig. 6). This is of essence, as some risk evaluations of PM from wood combustions employed organic ex tracts from PM only, thereby ignoring the bioavailability of the PAH contaminants adhering to PM [36 38]. Indeed, bioavailability appears to be one of the primary factors governing potential ad verse effects of PM, as demonstrated in Fig. 3 where PM\#05 (from a CC with a comparable PAH profile and concentration as PM\#03 
and PM\#04) presented with a much greater Ah receptor activity than PM\#03 and PM\#04. Similarly, using the same fuel and com bustion furnace, CC PM (PM\#08 and PM\#10) had a much greater activity in the PAH CALUX ${ }^{\circledR}$ than the corresponding PM sample from a combustion experiment, where the same pellet boiler was operated under suboptimal conditions (PM\#09), despite compara ble PAH values. However, there are more PAH congeners in the PM samples than the 16 routinely analyzed USEPA PAHs with binding capabilities to the Ah receptor. Moreover, as can be seen in Table S1, there are differences in the TEF values between the 16 USEPA PAHs. While B[a]P is one of the most potent and best char acterized $\mathrm{PAH}$, other PAHs with higher TEF values [39] also provide for high relative Ah receptor interactions, e.g. in the PAH CALUX ${ }^{\circledR}$ assay. In addition, and in complete agreement with results of the PAH CALUX ${ }^{\circledR}$ experiments, total PAH determination do not appear to be a good parameter for predicting activity in cell systems. An other important fact, which has to be considered, is that a direct comparison of all samples is only possible to a certain extent, as different fuel sources were applied, which is attributed to the use of two types of furnaces (pellet boiler and furnace for split logs). In deed, future experiments should more intensely focus on using comparable combustion setups and the variation of only one parameter, e.g. fuel source, as was in part achieved with PM\#08 PM\#10 (same pellet boiler and fuel source, but variation of operat ing conditions in order to obtain two different PM qualities).

Despite the aforementioned discussion points it must be also emphasized however, that there is the possibility of binding of li gands other than PAHs with affinity to the Ah receptor, which were not assessed in this study, as the focus was laid entirely on PAHs. As reviewed by Denison and Nagy, the Ah receptor appears a tran scription factor with a low restrictive binding site, thus allowing for binding of a diverse range of ligands [40]. Beside 2,3,7,8 tetra chlorodibenzo $\mathrm{p}$ dioxin (TCDD), which is the most potent activator of the AhR, PAHs display a high affinity to this receptor and are well characterized ligands [41]. However, many other naturally occurring exogenous as well as endogenous compounds could be identified or are in discussion to act as AhR ligands, although usu ally with much weaker activation potential [40].

As PM\#05, PM\#08 and PM\#10 had a similarly low EC content (Fig. 1) the question must be raised whether the low EC provides for lower PAH adherence. These findings were corroborated with results obtained in the PAH spiked activated charcoal experiments (Fig. 4C). If this were true than the presence of EC in PM would be beneficial with regard to $\mathrm{PAH}$ adsorption and thus lower bioavail ability rather than adverse in the context of human risk assess ment. Indeed, as the lung cancers observed in rats were considered a result of the lung overload with insoluble carbon par ticles (EC), EC were considered a misleading factor. Yet in consider ation of the findings regarding the PAH bioavailability in the PAH CALUX $^{\circledR}$ and the BALB/c 3T3 cell transformation assay, lack of EC in PM could prove to be more problematic than originally antici pated [8]. However, the PAH CALUX ${ }^{\circledR}$ and the BALB/c 3T3 cell transformation assays are mere in vitro assays with their serious limitations as to their predictive capability of human cancer risk. Thus the data generated with these in vitro systems primarily raise the question whether the current quest for technically optimized wood furnaces with CC result in the wanted enhanced health safety in humans. It must also be emphasized that the in vitro sys tems used were not employed to provide for information as to other potential biological endpoints, e.g. biomarkers of asthma or COPD.

Asthma, COPD and acute lower respiratory tract infections are associated with chronic exposure to biomass smoke, i.e. BSP $[7,42,43]$. Whether these diseases are a result of PM contaminants e.g. PAH or particle associated exhaustion of the macrophage re sponse is difficult to determine at this point of time. However, the Ah receptor is key to upstream signal transduction events that govern pathways involved in the immunological response, e.g. as observed with the Ah receptor substrate dioxin, cytokine regula tion as well as the reaction of the endothelium [44,45]. Current knowledge suggests that this is one of the first studies employing the Balb/c 3T3 cell transformation assay to assess the carcinogenic ity of wood combustion particles. This assay as well as other trans formation assays have already been successfully used for cigarette smoke and ambient air PM testing $[38,46]$. Hence, the PAH CALUX ${ }^{\circledR}$ system and the BALB/c 3T3 cell transformation assay may provide for a first assessment of the potential hazard of the biomass com bustion PM and thus a short term tool in combination with other screening tools for continuous observation of technical develop ments. This appears crucial, especially in view of the continuously increasing demand on renewable energy and the concurrent trend for installing biomass burners for household heating.

In conclusion, in the present study two qualities (IC and CC) of PM samples were analyzed, thereby focusing on the bioavailability and the carcinogenic potential of PAHs, which are typical by prod ucts of wood combustion. With the reporter gene assay it could be demonstrated that PAHs of all PM samples were bioavailable and also had the capacity to induce transformation foci in the BALB/c 3T3 cell transformation assay. However, despite that samples from IC tended to a higher PAH contamination, their biological activity in the two assays employed was lower than that of PM samples from CC with a concomitant lower PAH contamination. These find ings were found to be strongly associated with the EC amount present in the PM samples, thus higher EC favoring less bioavail ability of PAHs in PM. Consequently, a risk assessment based exclu sively on chemical analysis is insufficient, especially for complex, inhomogeneous samples, such as PM and more importantly, CC of wood biomass does not automatically imply higher quality and improved health safety.

\section{Conflict of interest statement}

The authors declare that there are no conflicts of interest.

\section{Funding information}

This work was supported by the German Federal Ministry of Environment, Grant \# BMU 03MAP144 to DRD and the Ecolinc and BE BASIC program of the Dutch Ministry of Economic Affairs, Agriculture and Innovation \& Ministry of Science and Education (to BvdB).

\section{Acknowledgements}

We would like to acknowledge the financial support of the Ger man Federal Ministry of Environment. We thank all our project partners (TUHH Institute of Environmental Technology and Energy Economics, Karlsruhe Institute of Technology, Leibniz Institute for Tropospheric Research), especially the German Biomass Research Center (DBFZ) and the Technologie und Förderzentrum (TFZ) that kindly provided the PM samples. Birte Hegemann and Iris Gut iérrez prepared the SEM images. Nicole Brauer conducted the BALB/c 3T3 transformation assays and Philipp Secker, Stefanie To felde and Samuel Roch performed parts of the PAH CALUX ${ }^{\circledR}$ assays. Special thanks to Bart Pieterse and Emiel Felzel for helpful com ments on the PAH CALUX ${ }^{\circledR}$ assay. 


\section{References}

[1] T. Nussbaumer, Combustion and co-combustion of biomass: fundamentals, technologies, and primary measures for emission reduction, Energy Fuels 17 (2003) 1510-1521.

[2] F.N.R.e.V. FNR, Bioenergy in Germany, Fachagentur Nachwachsende Rohstoffe e.V. (FNR), (2012).

[3] B.C. Boman, A.B. Forsberg, B.G. Jarvholm, Adverse health effects from ambient air pollution in relation to residential wood combustion in modern society, Scand. J. Work Environ. Health 29 (2003) 251-260.

[4] L.P. Naeher, M. Brauer, M. Lipsett, J.T. Zelikoff, C.D. Simpson, J.Q. Koenig, K.R Smith, Woodsmoke health effects: a review, Inhal Toxicol. 19 (2007) 67-106.

[5] C.A. Pope 3rd, D.W. Dockery, Health effects of fine particulate air pollution: lines that connect, J. Air Waste Manag. Assoc. 56 (2006) 709-742.

[6] IARC, IARC: Diesel Engine Exhaust Carcinogenic, Press Release $N^{\circ} 213$ (2012) $1-2$.

[7] R.J. Laumbach, H.M. Kipen, Respiratory health effects of air pollution: update on biomass smoke and traffic pollution, J. Allergy Clin. Immunol. 129 (2012) 3 11 ; quiz 12-13.

[8] T.W. Hesterberg, C.M. Long, W.B. Bunn, C.A. Lapin, R.O. McClellan, P.A. Valberg, Health effects research and regulation of diesel exhaust: an historical overview focused on lung cancer risk, Inhal Toxicol. 24 (Suppl. 1) (2012) 1-45.

[9] C.E. Bostrom, P. Gerde, A. Hanberg, B. Jernstrom, C. Johansson, T. Kyrklund, A Rannug, M. Tornqvist, K. Victorin, R. Westerholm, Cancer risk assessment indicators, and guidelines for polycyclic aromatic hydrocarbons in the ambient air, Environ. Health Perspect. 110 (Suppl. 3) (2002) 451-488.

[10] IARC, Overall evaluations of carcinogenicity: an updating of IARC monographs 1-42, IARC Monogr. Eval. Carcinog. Risks Hum. (Suppl. 7) (1987) 1-440.

[11] M. Mumtaz, J. George, Toxicological profile for polycyclic aromatic hydrocarbons, Agency Toxic Subst. Dis. Registry (1995) 1-458.

[12] R. Hoogenboom, T. Bovee, W. Traag. R. Hoogerbrugge, B. Baumann, L. Portier, G. van de Weg, J. de Vries, The use of the DR CALUX bioassay and indicator polychlorinated biphenyls for screening of elevated levels of dioxins and dioxin-like polychlorinated biphenyls in eel, Mol. Nutr. Food Res. 50 (2006 945-957.

[13] A.J. Murk, J. Legler, M.S. Denison, J.P. Giesy, C. van de Guchte, A. Brouwer, Chemical-activated luciferase gene expression (CALUX): a novel in vitro bioassay for Ah receptor active compounds in sediments and pore water Fundam. Appl. Toxicol. 33 (1996) 149-160.

[14] S. Sakai, H. Takigami, Integrated biomonitoring of dioxin-like compounds for waste management and environment, Ind. Health 41 (2003) 205-214.

[15] S.D. Seidel, V. Li, G.M. Winter, W.J. Rogers, E.I. Martinez, M.S. Denison, Ah receptor-based chemical screening bioassays: application and limitations for the detection of Ah receptor agonists, Toxicol. Sci. 55 (2000) 107-115.

[16] I. Windal, N. Van Wouwe, G. Eppe, C. Xhrouet, V. Debacker, W. Baeyens, E. De Pauw, L. Goeyens, Validation and interpretation of CALUX as a tool for the estimation of dioxin-like activity in marine biological matrixes, Environ. Sci. Technol. 39 (2005) 1741-1748.

[17] S. Asada, K. Sasaki, N. Tanaka, K. Takeda, M. Hayashi, M. Umeda, Detection of initiating as well as promoting activity of chemicals by a novel cell transformation assay using v-Ha-ras-transfected BALB/c 3T3 cells (Bhas 42 cells), Mutat. Res. 588 (2005) 7-21.

[18] A. Sakai, C. Suzuki, Y. Masui, A. Kuramashi, K. Takatori, N. Tanaka, The activities of mycotoxins derived from Fusarium and related substances in a short-term transformation assay using v-Ha-ras-transfected BALB/3T3 cells (Bhas 42 cells), Mutat. Res. 630 (2007) 103-111.

[19] S. Gauggel, C. Derreza-Greeven, J. Wimmer, M. Wingfield, B. van der Burg, D.R. Dietrich, Characterization of biologically available wood combustion particles in cell culture medium, ALTEX 29 (2012) 183-200.

[20] VDI, VDI 2465 Measurement of soot (immission) - Chemical analysis of elemental carbon by extraction and thermal desorption of the organic carbon, Kommission Reinhaltung der Luft im VDI und DIN - Normenausschuss KRdL, (1996).

[21] DIN, Air quality - Standard method for the measurement of the concentration of benzo[a]pyrene in ambient air EN 15549: 2008 (2008) 1-54.

[22] A. Sakai, M. Sato, Improvement of carcinogen identification in BALB/3T3 cell transformation by application of a 2-stage method, Mutat. Res. 214 (1989) 285-296.
[23] C. Muller, K. Ullmann, P. Steinberg, The grapevine-shoot extract Vineatrol30 inhibits the chemically induced malignant transformation of BALB/c-3T3 cells, J. Med. Food 14 (2011) 34-39.

[24] C.A. Reznikoff, J.S. Bertram, D.W. Brankow, C. Heidelberger, Quantitative and qualitative studies of chemical transformation of cloned $\mathrm{C} 3 \mathrm{H}$ mouse embryo cells sensitive to postconfluence inhibition of cell division, Cancer Res. 33 (1973) 3239-3249.

[25] J.M. Berg, A. Romoser, N. Banerjee, R. Zebda, C.M. Sayes, The relationship between $\mathrm{pH}$ and zeta potential of $\sim 30 \mathrm{~nm}$ metal oxide nanoparticle suspensions relevant to in vitro toxicological evaluations, Nanotoxicology 3 (2009) 276-283.

[26] K.W. Ragland, D.J. Aerts, A.J. Baker, Properties of wood for combustion analysis, Bioresour. Technol. 37 (1991) 161-168.

[27] T.A. Gasiewicz, A.S. Kende, G. Rucci, B. Whitney, J.J. Willey, Analysis of structural requirements for Ah receptor antagonist activity: ellipticines, flavones, and related compounds, Biochem. Pharmacol. 52 (1996) 1787-1803.

[28] M. Santostefano, J. Piskorska-Pliszczynska, V. Morrison, S. Safe, Effects of ligand structure on the in vitro transformation of the rat cytosolic aryl hydrocarbon receptor, Arch. Biochem. Biophys. 297 (1992) 73-79.

[29] C. Hueglin, C. Gaegauf, S. Künzel, H. Burtscher, Characterization of wood combustion particles: morphology, mobility, and photoelectric activity, Environ. Sci. Technol. 31 (1997) 3439-3447.

[30] A. Kocbach Bolling, J. Pagels, K.E. Yttri, L. Barregard, G. Sallsten, P.E. Schwarze, C. Boman, Health effects of residential wood smoke particles: the importance of combustion conditions and physicochemical particle properties, Part Fibre Toxicol. 6 (2009) 29.

[31] A.K. Frey, J. Tissari, K.M. Saarnio, H.J. Timonen, O. Tolonen-Kivimäki, M.A. Aurela, S.K. Saarikoski, U. Makkonen, K. Hytönen, J. Jokiniemi, R.O. Salonen, R.E.J. Hillamo, Chemical composition and mass size distribution of fine particulate matter emitted by a small masonry heater, Boreal Environ. Res. 14 (2009) 255-271.

[32] T. Nussbaumer, P. Hasler, Bildung und eigenschaften von aerosolen aus holzfeuerungen, Holz als Roh-und Werkstoff 57 (1999) 13-22.

[33] B.S. Choi, C.A.J. Fletcher, Turbulent particle dispersion in an electrostatic precipitator, Appl. Math. Model. 22 (1998) 1009-1021.

[34] I. Obernberger, T. Brunner, M. Joller, Characterisation and formation of aerosols and fly-ashes from fixed-bed biomass combustion, in: T. Nussbaumer (Ed.), Aerosols from Biomass Combustion, Zürich, Verenum, 2001.

[35] P.I. Jalava, R.O. Salonen, K. Nuutinen, A.S. Pennanen, M.S. Happo, J. Tissari, A. Frey, R. Hillamo, J. Jokiniemi, M.R. Hirvonen, Effect of combustion condition on cytotoxic and inflammatory activity of residential wood combustion particles, Atmos. Environ. 44 (2010) 1691-1698.

[36] A. Baulig, S. Singh, A. Marchand, R. Schins, R. Barouki, M. Garlatti, F. Marano, A. Baeza-Squiban, Role of paris $\mathrm{PM}(2.5)$ components in the pro-inflammatory response induced in airway epithelial cells, Toxicology 261 (2009) 126-135.

[37] I. Pagan, D.L. Costa, J.K. McGee, J.H. Richards, J.A. Dye, Metals mimic airway epithelial injury induced by in vitro exposure to Utah Valley ambient particulate matter extracts, J. Toxicol. Environ. Health A 66 (2003) 1087-1112.

[38] J.T. Zelikoff, J.M. Daisey, K.A. Traul, T.J. Kneip, Balbc/3T3 cell transformation response to extracts of organic air samples as seen by their survival in aggregate form, Mutat. Res. 144 (1985) 107-116.

[39] I.C. Nisbet, P.K. LaGoy, Toxic equivalency factors (TEFs) for polycyclic aromatic hydrocarbons (PAHs), Regul. Toxicol. Pharmacol. 16 (1992) 290-300.

[40] M.S. Denison, S.R. Nagy, Activation of the aryl hydrocarbon receptor by structurally diverse exogenous and endogenous chemicals, Annu. Rev. Pharmacol. Toxicol. 43 (2003) 309-334.

[41] J.V. Schmidt, C.A. Bradfield, Ah receptor signaling pathways, Annu. Rev. Cell Dev. Biol. 12 (1996) 55-89.

[42] S. Liu, Y. Zhou, X. Wang, D. Wang, J. Lu, J. Zheng, N. Zhong, P. Ran, Biomass fuels are the probable risk factor for chronic obstructive pulmonary disease in rural South China, Thorax 62 (2007) 889-897.

[43] M. Orozco-Levi, J. Garcia-Aymerich, J. Villar, A. Ramirez-Sarmiento, J.M. Anto, J. Gea, Wood smoke exposure and risk of chronic obstructive pulmonary disease, Eur. Respir. J. 27 (2006) 542-546.

[44] K.W. Bock, C. Kohle, Ah receptor: dioxin-mediated toxic responses as hints to deregulated physiologic functions, Biochem. Pharmacol. 72 (2006) 393-404.

[45] N.I. Kerkvliet, AHR-mediated immunomodulation: the role of altered gene transcription, Biochem. Pharmacol. 77 (2009) 746-760.

[46] D. Breheny, H. Zhang, E.D. Massey, Application of a two-stage Syrian hamster embryo cell transformation assay to cigarette smoke particulate matter, Mutat. Res. 572 (2005) 45-57. 